\title{
Variable Resistance of RMS to Interferon $\gamma$ Signaling
}

\author{
Katja Simon-Keller, Katharina Mößinger, Anna-Lena Bohlender, \\ Philipp Ströbel, and Alexander Marx \\ Institute of Pathology, University Medical Centre Mannheim, University of Heidelberg, 68135 Mannheim, Germany \\ Correspondence should be addressed to Katja Simon-Keller, katja.simon-keller@medma.uni-heidelberg.de
}

Received 12 March 2012; Accepted 10 April 2012

Academic Editors: A. M. Garcia-Lora, H. T. Khong, and X.-F. Le

Copyright ( $\odot 2012$ Katja Simon-Keller et al. This is an open access article distributed under the Creative Commons Attribution License, which permits unrestricted use, distribution, and reproduction in any medium, provided the original work is properly cited.

\begin{abstract}
Aims. Chimeric T cells directed to the $\gamma$-subunit of the fetal acetylcholine receptor (fAChR) produce large amounts of interferon$\gamma(\mathrm{IFN} \gamma)$ on coculture with fAChR-expressing rhabdomyosarcoma (RMS) cells prior to RMS cell death. The aim of this study was to elucidate whether IFN $\gamma$ blocks proliferation and survival of RMS cells and modulates expression of genes with relevance for cytotoxicity of chimeric T cells. Methods. Expression levels of IFN $\gamma$ receptor (IFNGR), AChR, MHCI, MHCII, and CIITA (class II transactivator) by RMS were checked by flow cytometry, qRT-PCR, and western blot. Proliferation and cell survival were investigated by annexin V and propidium iodide staining and MTT (thiazolyl-blue-tetrazolium-bromide) assay. Key phosphorylation and binding sites of IFNGRs were checked by DNA sequencing. Results. IFN $\gamma$ treatment blocked proliferation in 3 of 6 RMS cell lines, but reduced survival in only one. IFNGR was expressed at levels comparable to controls and binding sites for JAK and STAT1 were intact. Induction of several target genes (e.g., AChR, MHCI, and MHCII) by IFN $\gamma$ was detected on the RNA level but not protein level. Conclusions. IFN $\gamma$ does not significantly contribute to the killing of RMS cells by fAChR directed chimeric T cells. Signalling downstream of the IFNR receptor, including the posttranscriptional level, is impaired in most RMS cell lines.
\end{abstract}

\section{Introduction}

Interferon gamma (IFN $\gamma)$ plays a crucial role in tumor formation and protects host against growth of spontaneous or transplanted tumors $[1,2]$. Besides its immunomodulatory effects, IFN $\gamma$ has an influence on proliferation and induces apoptosis in vitro in many primary tumor cells and established tumor cell lines [3-6].

IFN $\gamma$ is the only member of the type II interferon family and is mainly produced by activated NK-cells and NKT cells [7], as well as $\mathrm{CD}^{+}{ }^{+} \mathrm{T}$-cells and cytotoxic $\mathrm{CD} 8^{+}$lymphocytes [8]. The active form of the cytokine is a dimer which binds to a heterodimeric receptor complex that consists of IFNGR1 and IFNGR2 subunits and is associated with two Janus kinase family members, Jak1 and Jak2. Changes in confirmation of receptor subunits after IFN $\gamma$ binding activate Jak1 and Jak2, which in turn phosphorylate IFNGR1 and generate a binding site for recruitment, phosphorylation, and dimerization of signal transducer and activator of transcription 1 (STAT1). After translocation of STAT1 homodimers to the nucleus and binding to GAS (IFN $\gamma$ activated sites) promotor elements, transcription of target genes is initiated [9-11], including MHC class I and II genes with immunomodulation function. Other genes affected by IFN $\gamma$ are the cyclin-dependent kinase inhibitors $\mathrm{p} 21^{\mathrm{WAF} 1 / \mathrm{CIP} 1}$ and $\mathrm{p} 27^{\mathrm{KIP}}$ [12], which mediate growth arrest, as well as PI3K, PKC, and different MAPK involved in STAT1 function [13-15]; recently genes such as Bik/Blk/Nbk with an importance for apoptotic pathways have been linked to IFN $\gamma$ response[16].

In the current study, we focus on Rhabdomyosarcoma (RMS), the most common form of soft tissue sarcoma, which mainly affects children and adolescents [17, 18]. RMS are subdivided in alveolar RMS (ARMS) and embryonal RMS (ERMS). While overall survival of patients with localized and resectable RMS improved significantly during the last decades, with an overall survival rate of $65 \%$, survival has remained poor in metastatic disease $[17,19,20]$. As a new treatment strategy for RMS, we have used chimeric $\mathrm{T}$ cells with a specificity against the fetal acetylcholine receptor (AChR) which is expressed on the surface of RMS 
[21]. Chimeric T cells are generated by transduction with expression vectors that code for a fully humanized chimeric antigen receptor (CAR) against the AchR $\gamma$ subunit [22]. Binding to target antigen results in strong IFN $\gamma$ secretion by chimeric $\mathrm{T}$ cells that exert specific cytotoxicity against RMS cell lines in vitro $[22,23]$. One of the previous studies suggested that IFN $\gamma$ might significantly contribute to the proapoptotic effects of RMS-directed chimeric T cells [23]. Furthermore, work by Poëa-Guyon et al. revealed that proinflammatory cytokines such as IFN $\gamma$ induce overexpression of $\mathrm{AChR}$, that is, the target of chimeric T cells, on the cell surface of RMS-like transformed thymic myoid cells [24]. Therefore, we studied the influence of IFN $\gamma$ on ARMS and ERMS cell lines, showing that most of them are resistant to even high concentrations of IFN $\gamma$ in terms of induction of apoptosis and AChR overexpression.

\section{Material and Methods}

2.1. Material. HT29 colon adenocarcinoma cell line was cultured in DMEM, 10\% (v/v) FCS. The alveolar RMS cell lines CRL2061, RH30, RH41 (all Pax3-FKHR translocation positive), and FLOH1 (translocation negative) were cultivated in RPMI1640 medium with $10 \%(\mathrm{v} / \mathrm{v})$ FCS. The embryonal RMS cell lines RD6 and TE671 were maintained in DMEM with $10 \%(\mathrm{v} / \mathrm{v})$ FCS.

Recombinant IFN $\gamma$ was purchased from R\&D Systems. The demethylation reagent $5^{\prime}$-Aza-2'-deoxycytidine was obtained from Sigma Aldrich (St. Louis, MO, USA). Mouse anti-human AChR antibodies against alpha and gamma subunit were obtained from GeneTex (Irvine, CA, USA); rat anti-human antibodies against alpha and gamma subunit of the AChR were a kind gift from S. Tzartos (Department of Biochemistry, Helenic Pasteur Institute, Athens, Greece); to detect human MHC class II (HLA-DRA), we used a mouse anti-human antibody (clone L243; kind gift from $\mathrm{H}$. Kalbacher; Interfaculty Institute of Biochemistry, University of Thübingen); mouse anti-human IFNGR1 and goat antihuman IFNGR2 antibody were purchased from R\&D Systems (Minneapolis, MN, USA). To detect CIITA we used a goat anti-human antibody from Santa Cruz Biotechnology (Santa Cruz, CA, USA), Caspase analysis was done with a mouse anti-human caspase 8 antibody from cell signalling (Danvers, MA, USA).

FITC-conjugated anti-mouse antibody was purchased from R\&D and TRI-conjugated antibody from CALTAG Laboratories. The PE-conjugated donkey anti-rat antibody and a FITC-conjugated donkey anti-goat antibody were from Jackson ImmunoResearch. Isotype-matched antibodies or secondary antibodies of irrelevant specificities were used as staining controls (Sigma Aldrich, St. Louis, MO, USA).

Horse-radish-peroxidases- (HRP-) conjugated antibodies (Santa Cruz) with specific specificity to primary antibodies were used as secondary antibody for western blot analyses.

2.2. Real-Time PCR. Total RNA was extracted from RMS cell lines and biopsy samples using TRIzol reagent (Invitrogen,
Carlsbad, CA, USA). Reverse transcription PCR (RT-PCR) was performed using "RevertAid H Minus First Strand cDNA Synthesis Kit" (Fermentas, St. Leon Roth, Germany). PCR amplification was performed by the "Step one plus system" with the following primer oligonucleotides: GAPDH fwd TGCACCACCAACTGCTTAGC; GAPDH rev GGCATGGACTGTGGTCATGAG; AChR $\alpha$ fwd AACACACACCACCGCTCAC AChR $\alpha$ rev: CTCGATGGCACTTTTCACCT; AChR $\gamma$ fwd: CTGTGCAGGACACCCAGTC; AChR $\gamma$ rev CGGGCCTTTCTCTAGCTTCT; MHCI fwd GAGGCAAGAGTTGTTCCTGC; MHCI rev CTCCCCACCTCCTCACATTA; MHCII fwd TGTAAGGCACATGGAGGTGA; MHCII rev ATAGGGCTGGAAAATGCTGA. The amplification products were detected with "Fast Sybr Green" (both Applied Biosystems, Carlsbad, CA, USA). Data were analysed by using the REST software tool (Qiagen, Hilden, Germany). Expression levels of the target mRNAs were normalized to endogenous GAPDH mRNA.

2.3. Sequencing. Sequencing of phosphorylation sites in IFNGR1 was done using ABI BigDye Terminator sequencing kit according to the manufacturer's instructions. The following primers were used for JAK binding site: IFNGR1 JAK fwd: CTGACTGATTGATGGCAGGT, IFNGR1 JAK rev: AGAATTGCAGAGCTGGGAAG and STAT1 phosphorylation site: IFNGR1 STAT fwd: GGAGGTGGTCTGTGAAGAGC and IFNGR1 STAT rev: TCTTTACCGCTATCATCCACAA.

2.4. Western Blot Analysis. Cells were washed three times with ice-cold PBS and incubated $30 \mathrm{~min}$ in $2 \%(\mathrm{w} / \mathrm{v})$ SDS, $60 \mathrm{mM}$ Tris $\mathrm{pH}$ 6.8, phosphatase, and protease inhibitor cocktail (ProteoBlock, Fermentas, St. Leon-Roth, Germany) on ice. Cellular debris was removed by centrifugation and proteins $(20 \mu \mathrm{g})$ were separated by $12 \%(\mathrm{w} / \mathrm{v})$ SDS polyacrylamid electrophoresis, followed by protein transfer to PVDF membranes (GE Healthcare, Fairfield, CT, USA). Membranes were blocked with $5 \%(\mathrm{w} / \mathrm{v})$ low-fat milk or BSA (PAA, Pasching, Austria) for $30 \mathrm{~min}$, incubated with primary antibody for $2 \mathrm{~h}$ at room temperature or over night at $4^{\circ} \mathrm{C}$, washed in TBS, $0,05 \%(\mathrm{w} / \mathrm{v})$ Tween and incubated with the HRP-conjugated secondary antibody. Binding of antibodies was visualized with the "ECL detection reagent" (GE Healthcare) and documented using the Chemi-smart 5100 (PEQLAB, Erlangen, Germany).

2.5. Cytotoxicity Assay. To analyze apoptotic effects towards target cells after different incubation periods with IFN $\gamma 1 \times$ $10^{4}$, tumor cells per well were seeded out in 96 well plates and incubated with $1 \%$ FCS $24 \mathrm{~h}$ before IFN $\gamma$ treatment, followed by addition of $100 \mathrm{ng} / \mathrm{mL}$ IFN $\gamma$ and incubation for $0,24,48,72$, and $96 \mathrm{~h}$. Cells were then incubated for $4 \mathrm{~h}$ with $20 \mu \mathrm{L}$ MTT $(5 \mathrm{mg} / \mathrm{mL})$. MTT salt was solved in $200 \mu \mathrm{L}$ DMSO and reduction of MTT by viable tumour cells was colorimetrically determined at an adsorbance wavelength of $560 \mathrm{~nm}$ and a reference wavelength of $670 \mathrm{~nm}$. The viability of tumour cells was calculated as the mean of three wells containing tumour cells, the background as the mean of three 

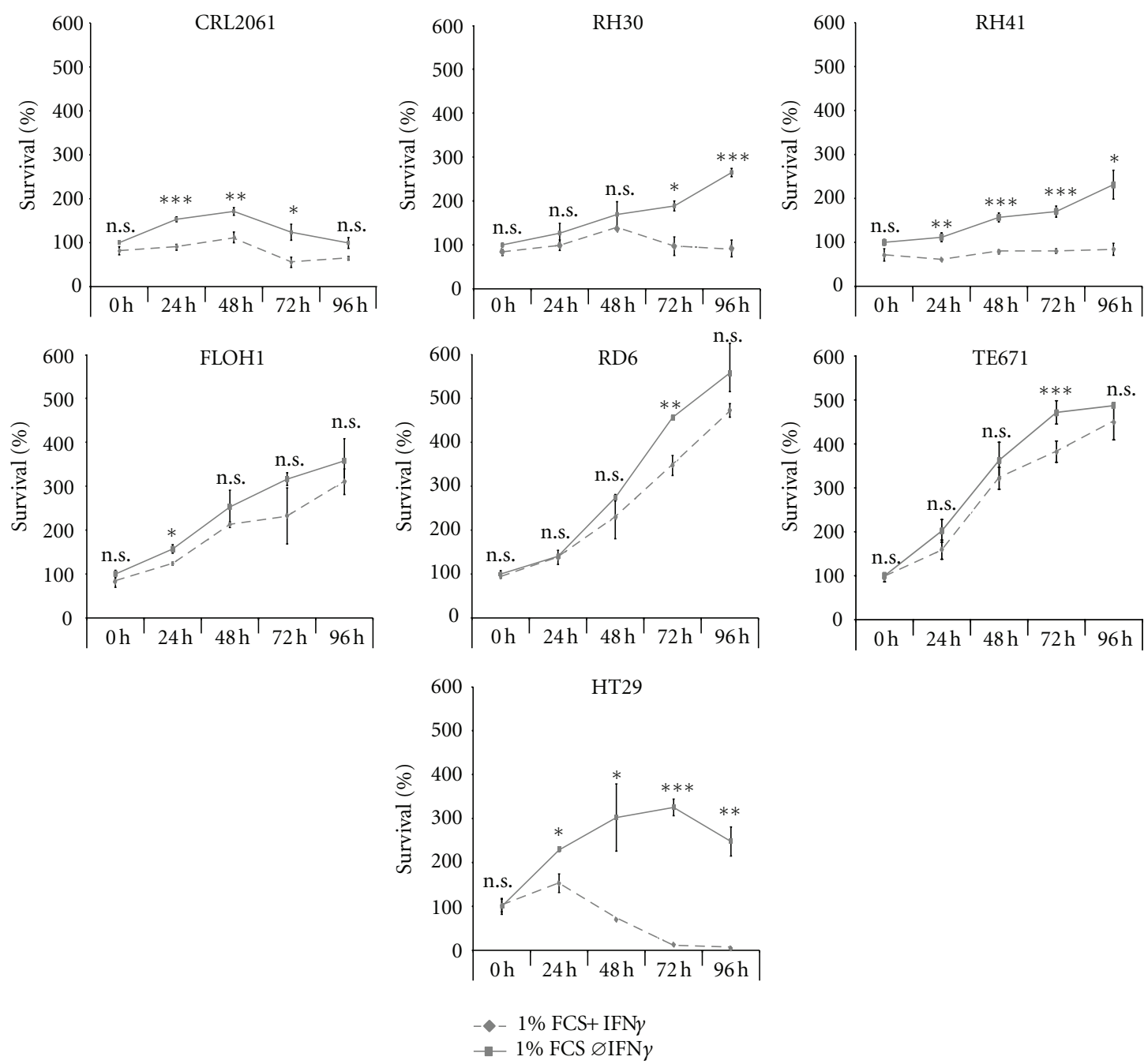

(a)

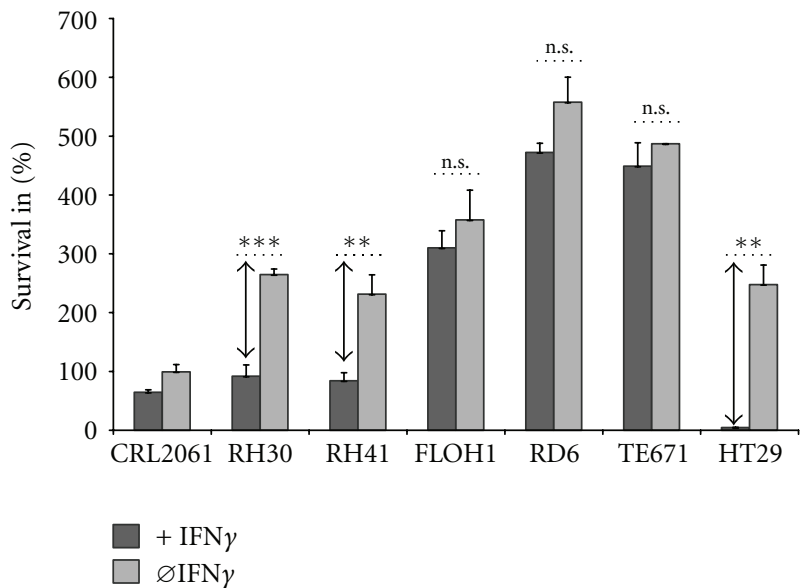

(b)

FIGURE 1: RMS cells are highly resistance against IFN $\gamma$ induced cell death. (a) Survival of RMS cell lines and HT29 control cells after IFN $\gamma$ treatment; cells were incubated for different periods of time with $100 \mathrm{ng} / \mathrm{mL}$ IFN $\gamma$ in starvation media with $1 \%$ FCS; survival of nontreated tumour cells $(0 \mathrm{~h})$ was set $100 \%$. Continuous line reflects cells without IFN $\gamma$ treatment; dashed line correspondent to IFN $\gamma$ treated cells; (b) summarizes effects after $96 \mathrm{~h}$ of treatment with (dark grey bars) and without (light grey bars) IFN $\gamma$. Data represent the mean of triplicates + SEM; one representative experiment out of 3 is shown. Statistical analysis was performed using Student's $t$-test. ${ }^{*} P<0.05$; ${ }^{* *} P<0.01$; $* * * P<0.001$ 


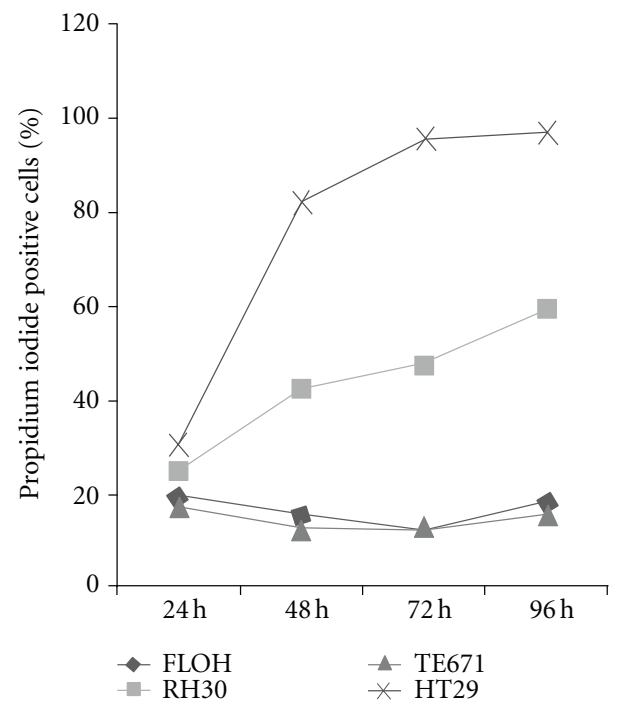

(a)
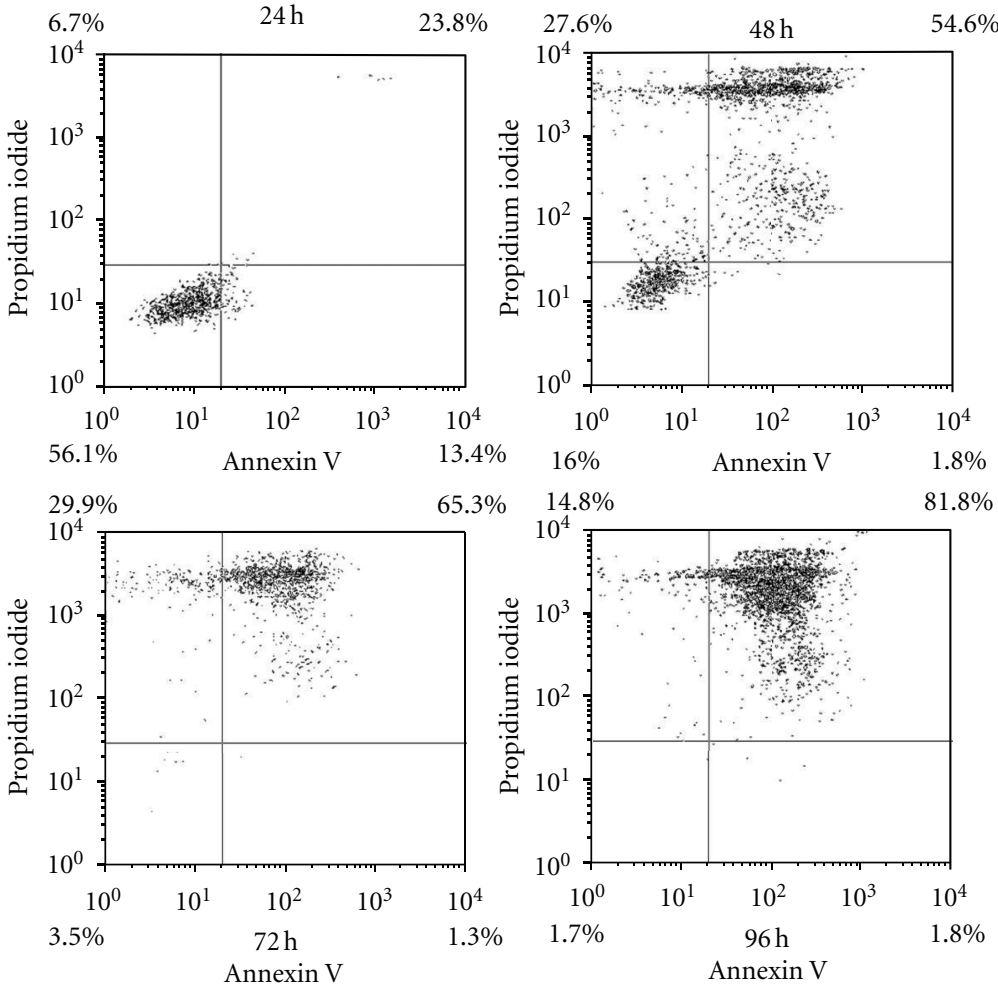

(b)

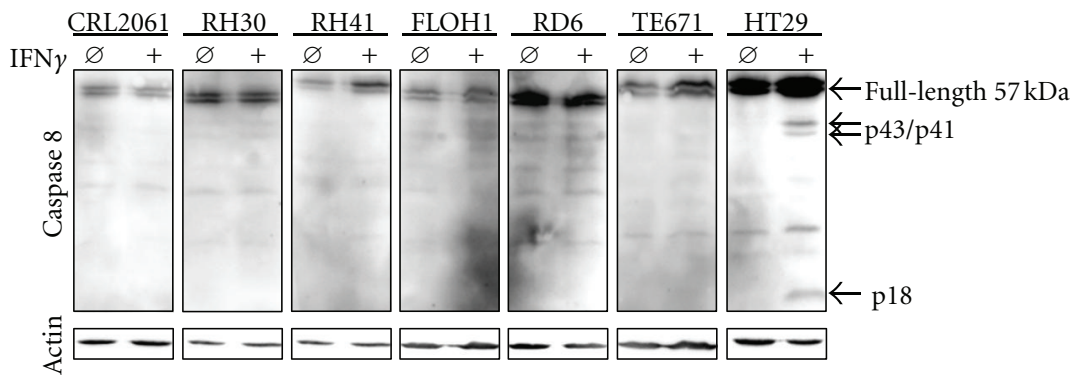

(c)

FIGURE 2: Detection of IFN $\gamma$ induced cell death by flow cytometry and western blot. (a and b) Apoptotic cell detection via flow cytometry of FLOH1, RH30, TE671, and HT29 cell lines after IFN $\gamma$ treatment; cells were incubated for different periods of time with $100 \mathrm{ng} / \mathrm{mL}$ IFN $\gamma$ in starvation media with $1 \%$ FCS and stained with propidium iodide and annexin V; (a) shows proportion of propidium iodide positive cells after IFN $\gamma$ treatment at different time points; (b) reflects the complete flow cytometry data for HT29 control cell lines; (c) western blot analysis of caspase 8 cleavage $24 \mathrm{~h}$ after IFN $\gamma$ treatment; $\beta$-actin serves as loading control.

wells containing medium. Survival of nontreated tumour cells $(0 \mathrm{~h})$ was set $100 \%$.

For demethylation experiments with $5^{\prime}$ aza- $2^{\prime}$-deoxycytidine (Sigma Aldrich, St. Louis, MO, USA) cells were pretreated with $10 \mu \mathrm{M}$ reagent and 1\% FCS and incubated for $72 \mathrm{~h}$ before treatment with IFN $\gamma$ as described [12].

2.6. Flow Cytometry. $2 \times 10^{5}$ cells were used per staining. After 3 washings in PBS primary antibodies were incubated for $1 \mathrm{~h}\left(4^{\circ} \mathrm{C}\right)$ and removed by washing with PBS; secondary antibody was incubated for $20 \mathrm{~min}$ at $4^{\circ} \mathrm{C}$ and removed by washing with PBS; flow cytometry analysis was performed on a BD FACSCalibur flow cytometer.

Detection of apoptotic and necrotic effects after incubation with $100 \mathrm{ng} / \mathrm{mL}$ IFN $\gamma$ was monitored using Annexin $\mathrm{V}$ and propidium iodide staining. Before IFN $\gamma$ treatment cells were cultivated in 1\% FCS for $24 \mathrm{~h}$ and incubated with $100 \mathrm{ng} / \mathrm{mL}$ IFN $\gamma$ for $0,24,48,72$, and $96 \mathrm{~h}$. At the end of the incubation period cells were collected by trypsination, washed three times in PBS, resuspended in $100 \mu \mathrm{L}$ Annexin $\mathrm{V}$ binding buffer, stained with $5 \mu \mathrm{L}$ Annexin $\mathrm{V}$ and $10 \mu \mathrm{L}$ PI (both Biolegend, San Diego, CA, USA) for $15 \mathrm{~min}$ at room 
IFNGR1
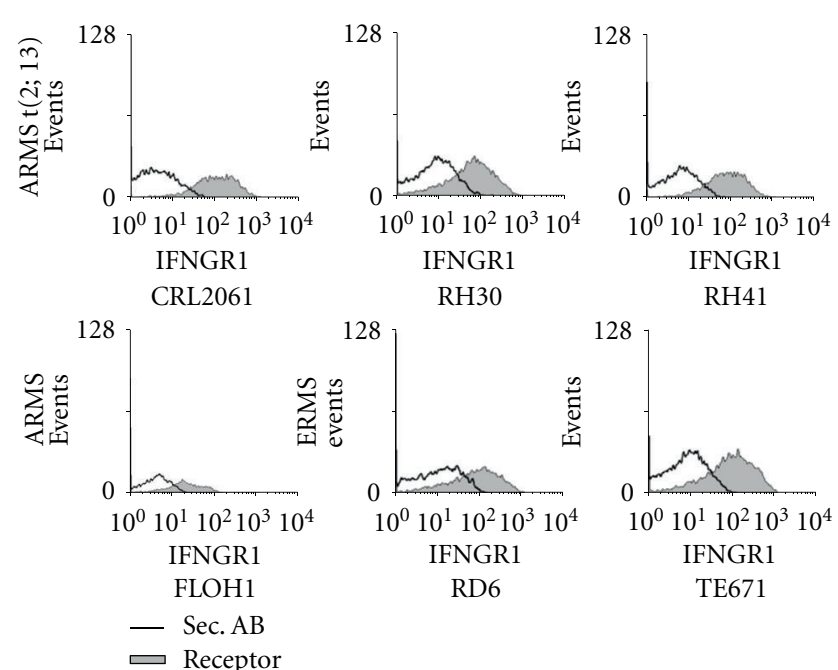

(a)
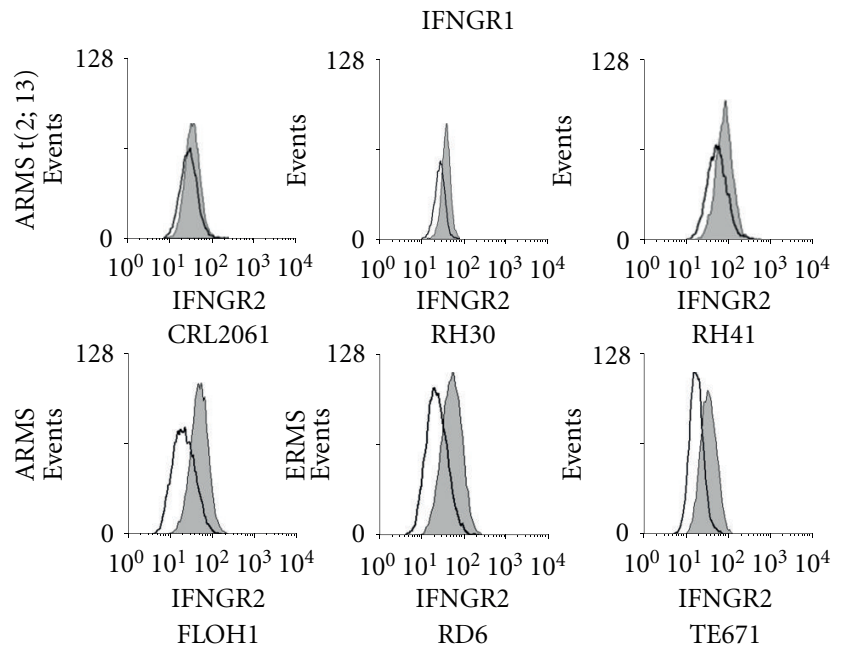

- Sec. AB

Receptor

(b)

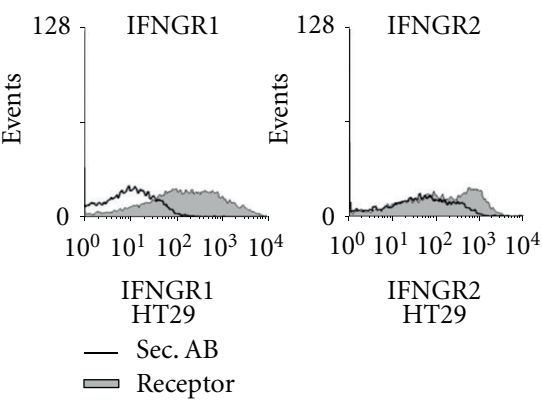

(c)

\begin{tabular}{|c|c|c|}
\hline IFNGR1 & $\begin{array}{c}\text { Phosphorylation site STAT1 } \\
\text { ATGTGGTTTATCATA }\end{array}$ & $\begin{array}{c}\text { JAK binding motif } \\
\text { GGACTTGGGTAA }\end{array}$ \\
\hline CRL2061 & ATGTGGTTTATCATA & GGACTTGGGTAA \\
\hline FLOH1 & ATGTGGTTTATCATA & GGACTTGGGTAA \\
\hline RD6 & ATGTGGTTTATCATA & GGACTTGGGTAA \\
\hline RH30 & ATGTGGTTTATCATA & GGACTTGGGTAA \\
\hline RH41 & ATGTGGTTTATCATA & GGACTTGGGTAA \\
\hline TE671 & ATGTGGTTTATCATA & GGACTTGGGTAA \\
\hline HT29 & ATGTGGTTTATCATA & GGACTTGGGTAA \\
\hline
\end{tabular}

(d)

$\begin{array}{lllllll}\text { CRL2061 RH30 } & \text { RH41 FLOH1 } & \text { RD6 } & \text { TE671 } & \text { HT29 }\end{array}$

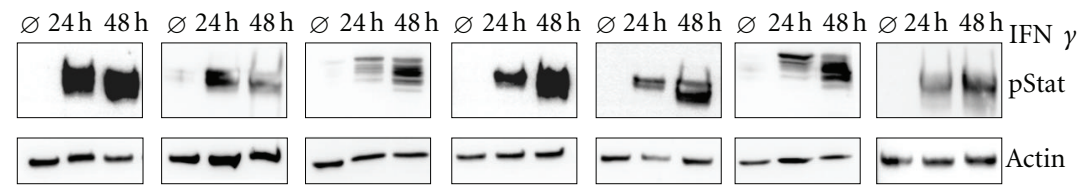

(e)

FIGURE 3: RMS cells show intact IFNRs and STAT1 phosphorylation in vitro. (a, b, and c) Flow cytometry data of IFNGR subunit expression in RMS and HT29 control cells lines; filled histograms represent expression levels using specific antibodies; open histograms represent isotype control stainings; (d) mutation analysis of STAT1 phosphorylation site and JAK binding motif in RMS cell lines and HT29 control cells; (e) western blot analysis of p STAT1 induction $24 \mathrm{~h}$ and $48 \mathrm{~h}$ after IFN $\gamma$ treatment; $\beta$-actin serves as loading control.

temperature, and analyzed by flow cytometry after addition of $400 \mu \mathrm{L}$ Annexin V binding buffer.

2.7. Statistical Analysis. For statistical analysis an unpaired $t$-test was applied using the GraphPad Software (San Diego, CA, USA).

\section{Results}

3.1. RMS Cells Are Highly Resistance against IFNy-Induced Cell Death. As shown before [23], killing of RMS cells following coculture with fAChR-specific chimeric T cells is preceded by the production of large amounts of IFN $\gamma$. To examine whether IFN $\gamma$ contributes to RMS cell death, we treated various RMS cell lines with $100 \mathrm{ng} / \mathrm{mL}$ IFN $\gamma$ and determined survival at different time points. The IFN $\gamma$ sensitive colon carcinoma cell line HT29 served as positive control [25].

HT29 cells started to undergo apoptosis $24 \mathrm{~h}$ after the beginning of IFN $\gamma$ treatment. Their proliferation decreased in parallel, resulting in significantly reduced numbers of viable cells after $48 \mathrm{~h}(69 \%)$ and $72 \mathrm{~h}(10 \%)$ (Figure 1(a)). As opposed to HT29 cells, ERMS cell lines RD6 and TE671 and the translocation negative alveolar ARMS cell line FLOH maintained proliferation and survival during IFN $\gamma$ 


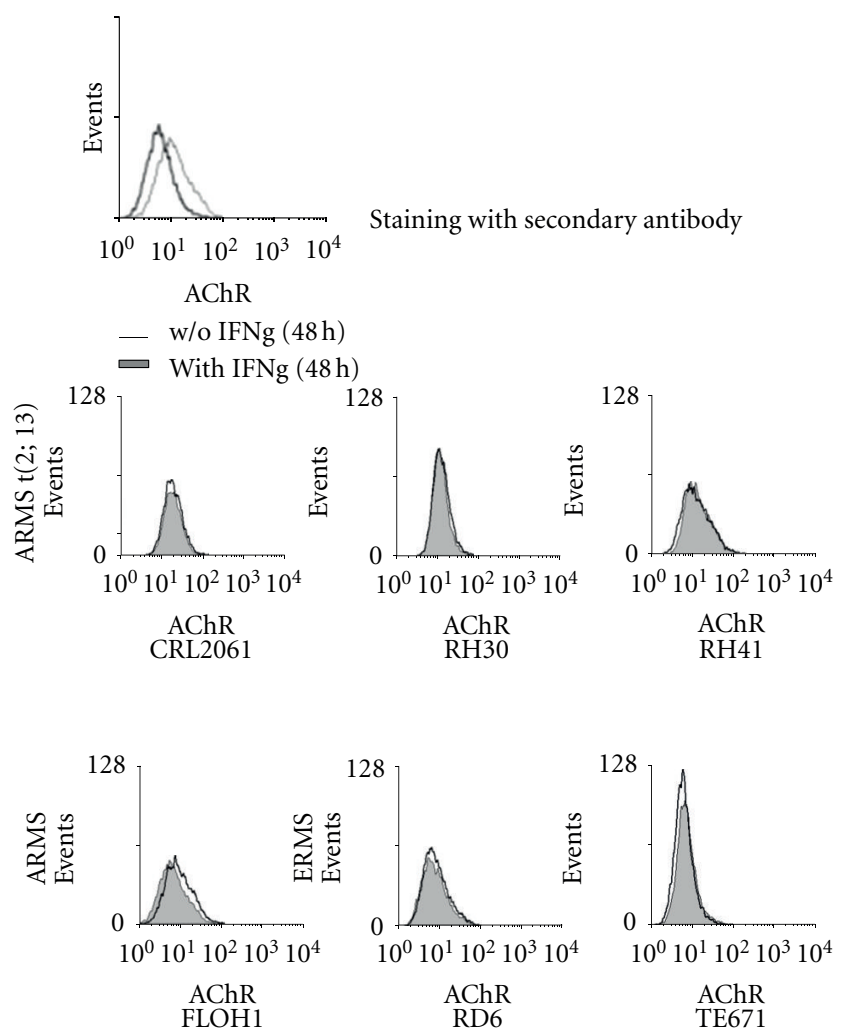

FIGURE 4: IFN $\gamma$ treatment does not alter protein expression of AChR. Induction of AChR $\gamma$ in RMS cell lines $48 \mathrm{~h}$ after IFN $\gamma$ treatment $(100 \mathrm{ng} / \mathrm{mL})$; filled histograms represent expression levels after incubation with IFN $\gamma$; open histograms represent expression levels without IFN $\gamma$ incubation.

incubation periods up to $96 \mathrm{~h}$ (Figure $1(\mathrm{~b})$ ) with only minor effects on cell growth. By contrast, IFN $\gamma$ elicited reduced proliferation and growth arrest without cell death in the translocation-positive ARMS cell lines CRL2061 and RH41 (Figure 1(a)), while only RH30 cells showed a decline in viability after $72 \mathrm{~h}$ (Figure 1(a)).

Apoptosis was checked in RH30, FLOH1, TE671, and HT29 cells by Annexin V/Propidium iodide (PI) double staining and caspase 8 cleavage assay. Percentage of PI positive cells after $96 \mathrm{~h}$ of treatment approached $100 \%$ in HT29 cells, $60 \%$ in RH30 cells and $<20 \%$ in the other, IFN $\gamma$-resistant cell lines (Figures 2(a) and 2(b)). Surprisingly, caspase 8 cleavage after $24 \mathrm{~h}$ (Figure $2(\mathrm{c})$ ), $48 \mathrm{~h}$, and $96 \mathrm{~h}$ (not shown) was only observed in HT29 cells but not in any RMS cell line tested, including apoptosis-prone RH30 cells (Figure 2(c) and data not shown).

\subsection{RMS Cells Show Intact IFNRs and STAT1 Phosphorylation} In Vitro. Since IFN $\gamma$ resistance could be due to diminished expression of IFNGR subunits, we next analyzed expression of the IFNGR1 and IFNR2 subunits on RMS cell lines. Apart from CRL2061 cells, that showed barely detectable IFNGR2 expression levels by FACS, both subunits were expressed on the surface of the other RMS cell lines (Figures 3(a) and 3(b)). IFN $\gamma$ treatment ( $48 \mathrm{~h}$ ) induced normal [26] decline of IFNGR1 by receptor internalization (not shown) in all tested cell lines. Sequencing of essential phosphorylation sites for
JAK binding and STAT1 phosphorylation revealed wild-type sequences (Figure 3(d)). Furthermore, we found that RMS cell lines express high levels of pStat after different incubation periods with IFN $\gamma$ (Figure 3(e)).

3.3. IFNy Treatment Does Not Alter Protein Expression of FAchR and MHCII by RMS cells. To check whether resistance of most RMS cell lines against IFN $\gamma$-mediated killing reflects a facet of a broader block of IFN $\gamma$-driven gene expression, we analyzed AChR and MHC expression on RMS cell lines after incubation with IFN $\gamma$ for up to $72 \mathrm{~h}$. In contrast to a previous report about IFN $\gamma$-driven AChR induction in RMS-like transformed myoid cells [24], AChR expression on RMS cell was not altered either by IFN $\gamma$ treatment alone (Figure 4) or when combined with TNF $\alpha$ (data not shown). As to bona fide IFN $\gamma$ targets, expression of MHC class II and its upstream regulator, CIITA, was not inducible in any RMS cell line (Figures 5(a) and 5(c)), while MHC class I expression was slightly inducible in RH41, RD6, and TE671 but only marginally in CRL2061, RH30, and FLOH1 cells (Figure 5(b)). Of note, IFN $\gamma$-susceptible, apoptosis-prone HT29 cells exhibited strong induction of MHCI, MHCII (Figure 5(d)), and CIITA (Figure 5(c)) expression on IFN $\gamma$ treatment.

3.4. Transcriptional Increase of Target Genes after IFNy Treatment. To check whether the block of AChR and 


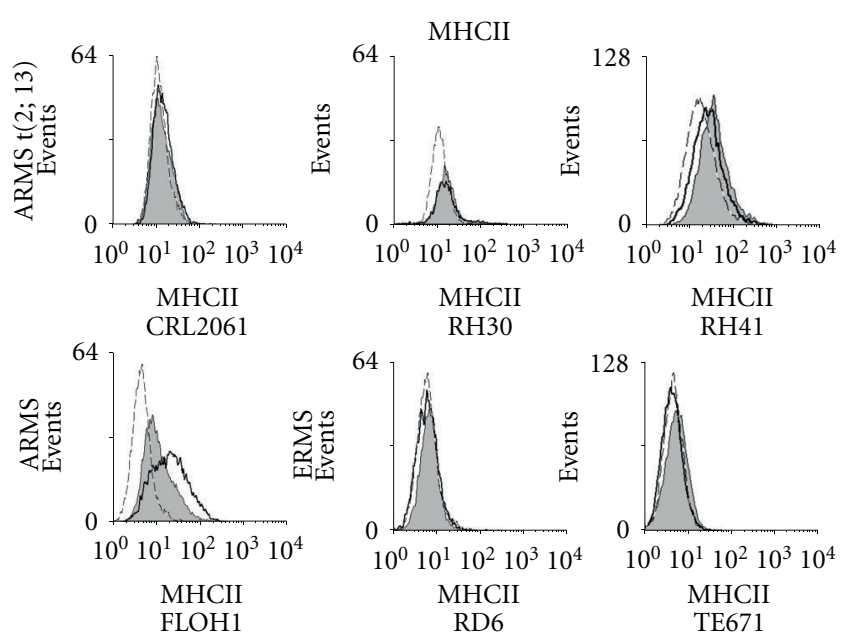

(a)

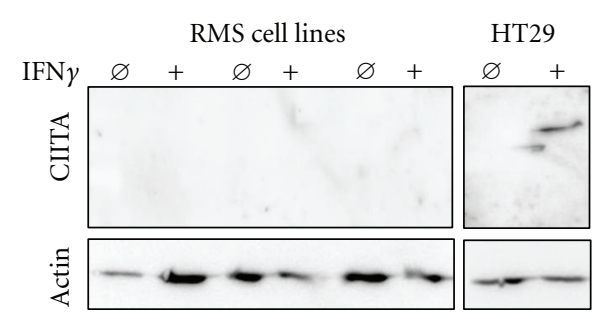

(c)

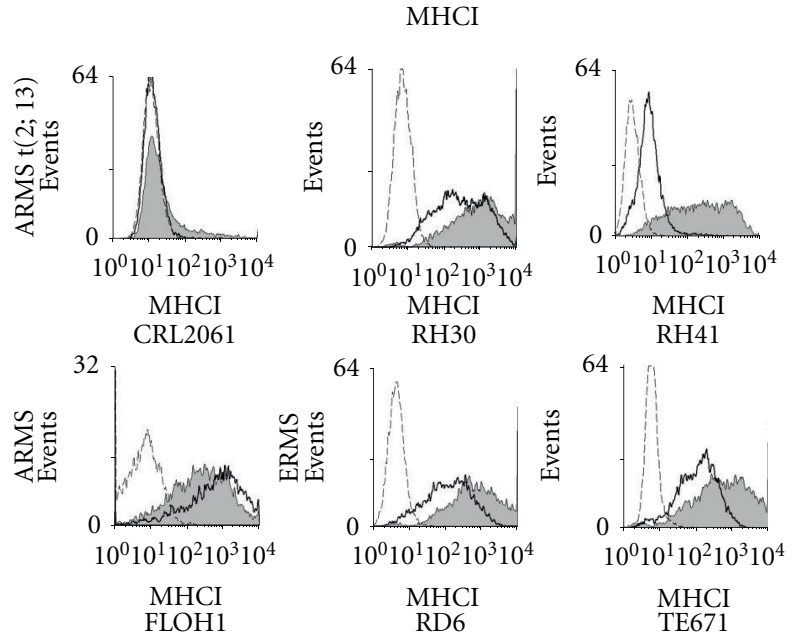

(b)

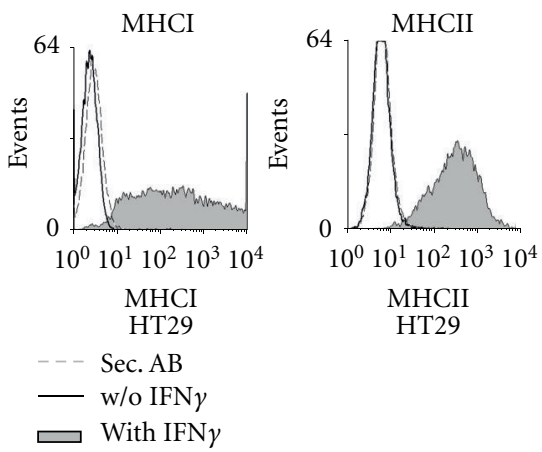

(d)

FIGURE 5: IFN $\gamma$ treatment does not alter protein expression of MHCII by RMS cells. (a, b) Induction of MHCII and MHCI in RMS cell lines and (d) in HT29 control cells $48 \mathrm{~h}$ after IFN $\gamma$ treatment $(100 \mathrm{ng} / \mathrm{mL})$; grey filled histograms represent expression levels after incubation with IFN $\gamma$; open histograms represent expression levels without IFN $\gamma$ incubation; broken lines represent the negative control (secondary antibody). In (d), the broken lines overlap with the lines of the open histograms; (c) western Blot Analysis of CIITA induction $48 \mathrm{~h}$ after IFN $\gamma$ treatment $(100 \mathrm{ng} / \mathrm{mL}) ; \beta$-actin serves as loading control.

MHC protein expression occurs on the transcriptional or posttranscriptional level, we analyzed expression of MHCI, MHCII, and two AChR subunit genes $(\alpha$ and $\gamma$ ) by qRT-PCR (Figure 6). IFN $\gamma$ increased MHCI (2- to 7-fold) and MHCII (3- to 8.000-fold) mRNA levels in RMS cells. These increases were much lower than in HT29 cells (17-fold for MHCI and 12.700.000-fold for MHCII). Transcripts of AChR subunits were significantly increased only in FLOH1 and TE671 cells, but neither in the other RMS cell lines nor HT29 cells.

3.5. Blockade of IFNy Response Genes in RMS Cannot Be Abrogated by Demethylation. Chen et al. [27] showed hypermethylation of $\mathrm{p} 21^{\mathrm{WAF}}$ promoter regions in RMS and demethylation with $5^{\prime}$ aza $2^{\prime}$ deoxycytidine ( $5^{\prime}$ aza) reactivates $\mathrm{p} 21^{\mathrm{WAF}}$ expression. We found similar effects following demethylation that was paralleled by cell cycle arrest in all RMS cell lines. By contrast, demethylation rendered CRL2061, RH30, and RH41 susceptible to IFN $\gamma$-induced cell death (Figure 7). Furthermore, pretreatment of RMS cell lines with $5^{\prime}$ aza had no impact on the defective induction of MHCII or AChR expression by IFN $\gamma$ (data not shown).

\section{Discussion}

In search of novel treatment options for otherwise refractory RMS we generated an immunoreceptor against the RMSspecific fAChR and used chimeric T cells (cTCs) to target RMS cells. However, RMS cell death on coculture with cTCs was rather protracted although cTCs exhibited strong IFN $\gamma$ secretion on antigen recognition $[22,23]$. To explain the delayed death response of RMS cells the hypothesis has been put forward that granzyme B-driven apoptotic pathways may be attenuated and that locally secreted IFN $\gamma$ may contribute to RMS cell death [23]. Furthermore, an inductive effect of IFN $\gamma$ on the expression of fAChR, that is, the chimeric T-cell target, has been suggested in RMS-like cells [24]. To address these hypotheses, we here investigated the impact of IFN $\gamma$ on proliferation, apoptosis, and fAChR expression in RMS cell lines. 


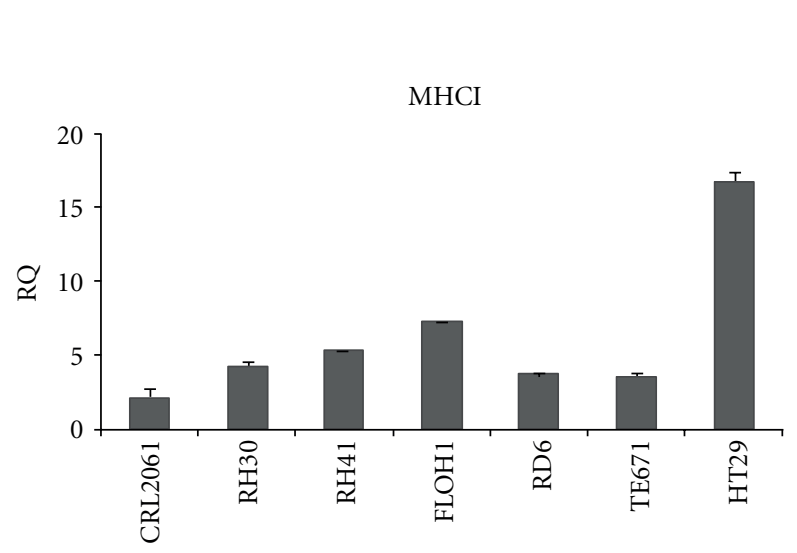

(a)

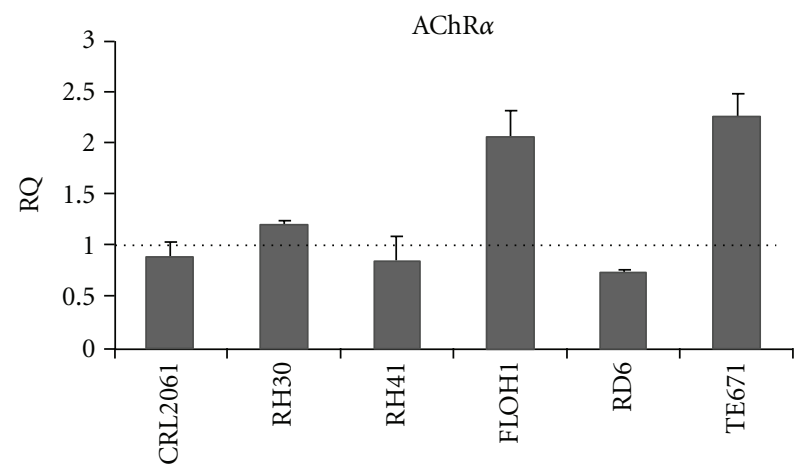

(c)

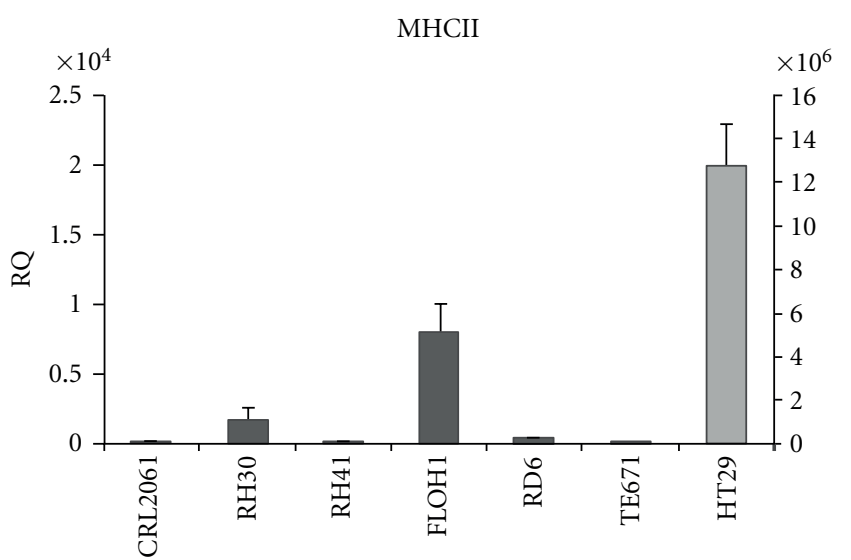

(b)

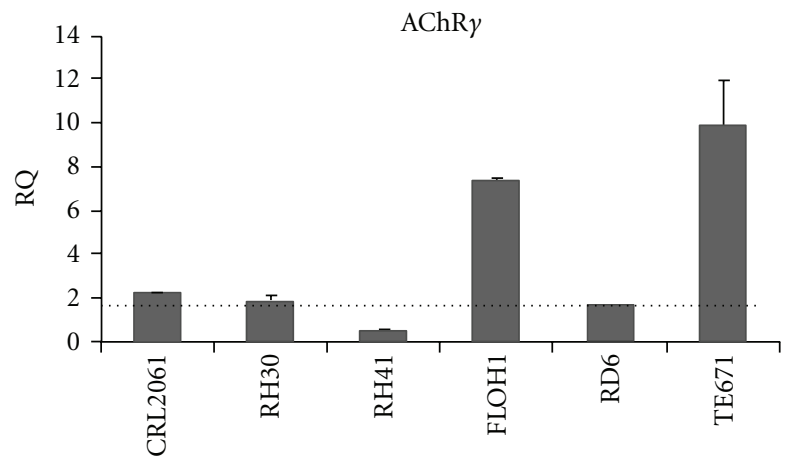

(d)

FIGURE 6: Transcriptional increase of target genes after IFN $\gamma$ treatment. Relative mRNA expression of MHCI (a) and MHCII (b) in RMS cells and HT29 control cells as well as AChR $\alpha$ (c) and $\gamma(\mathrm{d})$ in RMS cells after IFN $\gamma$ treatment was determined by qRT-PCR, normalized to GAPDH specific signals and compared to nontreated cells. Expression of each of the respective nontreated cells was arbitrarily set as 1.0. RQ, relative quotient. Data represent the mean \pm SEM of one representative experiment out of three. Beware of different scales used for HT29 cells (light grey bar) in (b).

Our major finding was that IFN $\gamma$ has antiproliferative effects on CRL2061 and RH41 and apoptotic effects on RH30 while other lines (FLOH1, RD6, and TE671) appeared refractory (Figure 2). However, apoptotic effects even in RH30 cells were smaller than in highly IFN $\gamma$-sensitive HT29 colon carcinoma cells that served as positive control. In addition experiments with IFN $\gamma$ target genes like MHCI, MHCII, and AChR illustrated a diminished alteration in gene expression after IFN $\gamma$ treatment. Lack of IFNGR2 expression-one of the limiting factors in IFN $\gamma$ signalling [28] — could be excluded (Figure 3). Furthermore, mutations in two essential binding sites in IFNGR1, which are required for receptor function- the JAK binding motive LPKS and Stat1 binding site YDKPH with the essential phosphorylation site $\mathrm{Y}_{440}^{30}$-were also excluded by sequencing (Figure 3(d)). Indeed, phosphorylation of Stat 1 that is necessary for successful IFN $\gamma$ signalling $[29,30]$, was comparable in RMS cells to phosphorylation in a highly IFN $\gamma$-sensitive control cell line (Figure 3(e)).

Since it is known that a broad spectrum of tumor cells lack MHC presentation and show hypermethylation of IFN $\gamma$ target genes such as CIITA [31], we treated RMS cells with the demethylation reagent 5 'aza 2 'deoxycytidine. Further addition of IFN $\gamma$ resulted in growth arrest and induced cell death in some but not all cell lines (Figure 7). However, induction of MHCII and AChR expression was not achieved. Our results fit in part to those of Chen et al., who described inhibition of cyclin-dependent kinase inhibitor p21 ${ }^{\text {WAF1 }}$ by methylation of SIE-1 promotor elements that resulted in reduced cell cycle control [27] and increased growth. Taken together, hypermethylation of IFN $\gamma$ target genes may be operative in defective cycle control, but may not explain diminished IFN $\gamma$ responses of other target genes. Indeed, the study of Londhe et al. shows that CIITA induction is possible by the combined treatment of RMS cell lines with histone deacetylase (HDAC) inhibitors and demethylation agents, indicating a complex block of accessibility to some promoters in RMS cell lines [32]. However, even this mechanism may not apply to all promoters, considering our finding that some IFN $\gamma$ response genes showed upregulation of transcription that did not translate into protein expression. Therefore, we hypothesize that (a) higher levels of mRNA of IFN $\gamma$ target genes may be required for effective translation, which can be achieved by changes in epigenetic modifications and-not 

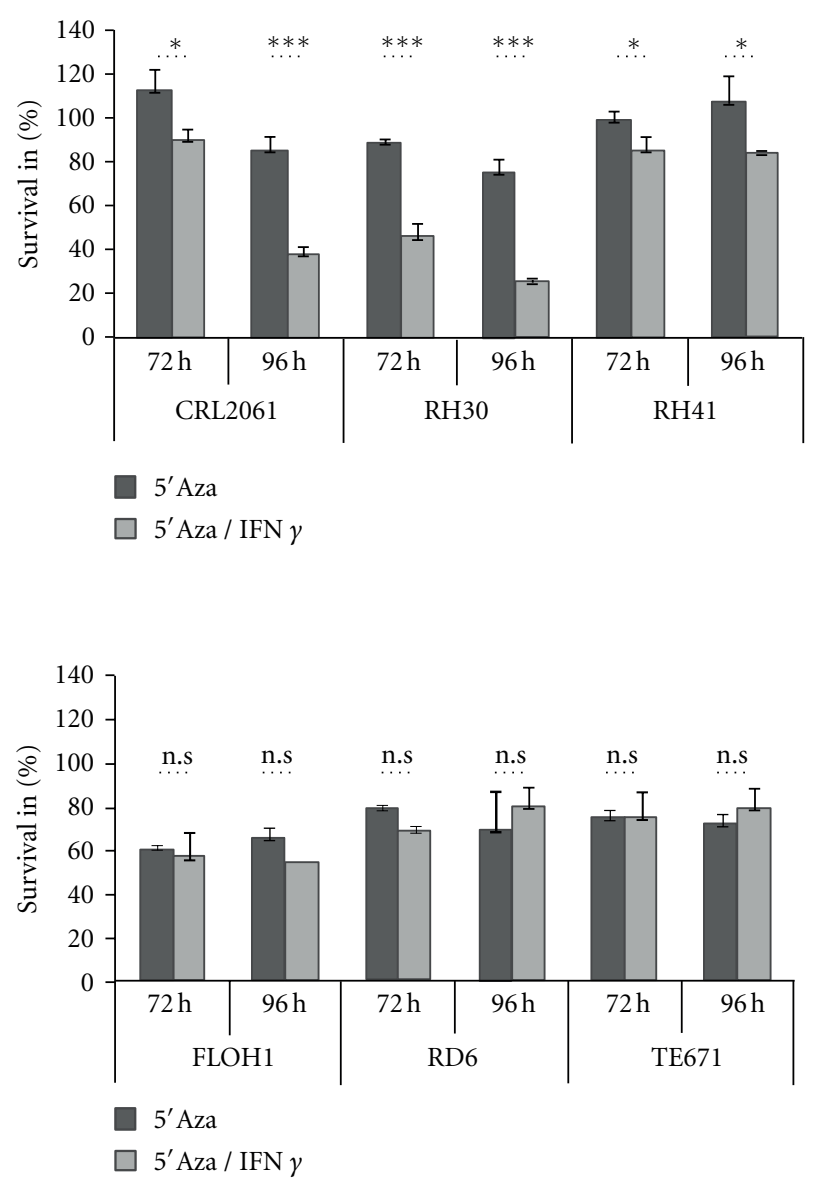

FIGURE 7: Blockade of IFN $\gamma$ response genes in RMS cannot be abrogate by demethylation. Survival of RMS cell lines after $5^{\prime}$ Aza (dark grey bars) and combined treatment of $5^{\prime} \mathrm{Aza}$ and IFN $\gamma$ (light grey bars); cells were incubated for $72 \mathrm{~h}$ with $100 \mu \mathrm{M} \mathrm{5}$ ' aza $2^{\prime}$ deoxycytidine $\left(5^{\prime} \mathrm{Aza}\right)$ in starvation media with $1 \%$ FCS before treatment with IFN $\gamma$ as described; survival of nontreated tumour cells $(0 \mathrm{~h})$ was set $100 \%$. ${ }^{*} P<0.05$; ${ }^{* *} P<0.01$; ${ }^{* * *} P<0.001$.

mutually exclusive-(b) there could be a posttranscriptional block, for example, by miRNAs, with influence on IFN $\gamma$ dependent protein expression [33].

The current findings have therapeutic perspectives. In vivo, defective responsiveness to IFN $\gamma$ is associated with more aggressive tumor behaviour, while IFN $\gamma$-responsive tumors have a better chance to be kept in check by the immune system [34-36]. Overcoming tumor escape by breaking IFN $\gamma$ resistance in RMS is, therefore, worth to be tested as an adjunct to immunotherapies based on vaccination or adoptive transfer of tumor-reactive cytotoxic effector cells.

\section{Acknowledgments}

The author thank Dr. S. Tzartos, Helenic Pasteur Institute, Athens, Greece, for the AChR antibodies and Dr. H. Kalbacher, Interfaculty Institute of Biochemistry, University of Tübingen, for an antibody to detect human MHC class II.
The work was supported by the Deutsche Krebshilfe (Grant no. 109891).

\section{References}

[1] G. P. Dunn, A. T. Bruce, H. Ikeda, L. J. Old, and R. D. Schreiber, "Cancer immunoediting: from immunosurveillance to tumor escape,” Nature Immunology, vol. 3, no. 11, pp. 991-998, 2002.

[2] G. P. Dunn, H. Ikeda, A. T. Bruce et al., "Interferon- $\gamma$ and cancer immunoediting," Immunologic Research, vol. 32, no. 13, pp. 231-245, 2005.

[3] H. Ikeda, L. J. Old, and R. D. Schreiber, "The roles of IFN $\gamma$ in protection against tumor development and cancer immunoediting," Cytokine and Growth Factor Reviews, vol. 13, no. 2, pp. 95-109, 2002.

[4] L. Wall, F. Burke, C. Barton, J. Smyth, and F. Balkwill, "IFN- $\gamma$ induces apoptosis in ovarian cancer cells in vivo and in vitro," Clinical Cancer Research, vol. 9, no. 7, pp. 2487-2496, 2003.

[5] M. C. Zhang, H. P. Liu, L. L. Demchik, Y. F. Zhai, and D. J. Yang, "LIGHT sensitizes IFN $\gamma$-mediated apoptosis of HT29 human carcinoma cells through both death receptor and mitochondria pathways," Cell Research, vol. 14, no. 2, pp. 117124, 2004.

[6] T. Toyonaga, O. Hino, S. Sugai et al., "Chronic active hepatitis in transgenic mice expressing interferon- $\gamma$ in the liver," Proceedings of the National Academy of Sciences of the United States of America, vol. 91, no. 2, pp. 614-618, 1994.

[7] M. Moreno, J. W. Molling, S. Von Mensdorff-Pouilly et al., "IFN- $\gamma$-producing human invariant NKT cells promote tumor-associated antigen-specific cytotoxic T cell responses," Journal of Immunology, vol. 181, no. 4, pp. 2446-2454, 2008.

[8] J. R. Schoenborn and C. B. Wilson, "Regulation of interferon$\gamma$ during innate and adaptive immune responses," Advances in Immunology, vol. 96, pp. 41-101, 2007.

[9] B. Saha, S. Jyothi Prasanna, B. Chandrasekar, and D. Nandi, "Gene modulation and immunoregulatory roles of Interferon $\gamma$," Cytokine, vol. 50, no. 1, pp. 1-14, 2010.

[10] K. Schroder, P. J. Hertzog, T. Ravasi, and D. A. Hume, "Interferon- $\gamma$ : an overview of signals, mechanisms and functions," Journal of Leukocyte Biology, vol. 75, no. 2, pp. 163-189, 2004.

[11] I. M. Kerr, A. P. Costa-Pereira, B. F. Lillemeier, and B. Strobl, "Of JAKs, STATs, blind watchmakers, jeeps and trains," FEBS Letters, vol. 546, no. 1, pp. 1-5, 2003.

[12] B. Chen, L. He, V. H. Savell, J. J. Jenkins, and D. M. Parham, "Inhibition of the interferon- $\gamma /$ signal transducers and activators of transcription (STAT) pathway by hypermethylation at a STAT-binding site in the p21(WAF1) promoter region," Cancer Research, vol. 60, no. 12, pp. 3290-3298, 2000.

[13] E. B. Burova, I. S. Smirnova, I. V. Gonchar, A. N. Shatrova, and N. N. Nikolsky, "Inhibition of the EGF receptor and ERK1/2 signaling pathways rescues the human epidermoid carcinoma A431 cells from IFN $\gamma$-induced apoptosis," Cell Cycle, vol. 10, no. 13, pp. 2197-2205, 2011.

[14] H. Nguyen, C. V. Ramana, J. Bayes, and G. R. Stark, "Roles of phosphatidylinositol 3-kinase in interferon- $\gamma$-dependent phosphorylation of STAT1 on serine 727 and activation of gene expression," Journal of Biological Chemistry, vol. 276, no. 36, pp. 33361-33368, 2001.

[15] G. G. Choudhury, "A linear signal transduction pathway involving phosphatidylinositol 3-kinase, protein kinase $\mathrm{C} \varepsilon$, and MAPK in mesangial cells regulates interferon- $\gamma$-induced 
STAT1 $\alpha$ transcriptional activation," Journal of Biological Chemistry, vol. 279, no. 26, pp. 27399-27409, 2004.

[16] Y. A. Mebratu, B. F. Dickey, C. Evans, and Y. Tesfaigzi, "The BH3-only protein BikJBlkJNbk inhibits nuclear translocation of activated ERK1J2 to mediate IFN $\gamma$-induced cell death," Journal of Cell Biology, vol. 183, no. 3, pp. 429-439, 2008.

[17] S. Gallego Melcón and J. Sánchez de Toledo Codina, "Molecular biology of rhabdomyosarcoma," Clinical and Translational Oncology, vol. 9, no. 7, pp. 415-419, 2007.

[18] A. Ferrari, I. Sultan, T. T. Huang et al., "Soft tissue sarcoma across the age spectrum: a population-based study from the surveillance epidemiology and end results database," Pediatric Blood and Cancer, vol. 57, no. 6, pp. 943-949, 2011.

[19] W. M. Crist, J. R. Anderson, J. L. Meza et al., "Intergroup Rhabdomyosarcoma Study-IV: results for patients with nonmetastatic disease," Journal of Clinical Oncology, vol. 19, no. 12, pp. 3091-3102, 2001.

[20] T. M. Dantonello, C. Int-Veen, D. Harms et al., "Cooperative trial CWS-91 for localized soft tissue sarcoma in children, adolescents, and young adults," Journal of Clinical Oncology, vol. 27, no. 9, pp. 1446-1455, 2009.

[21] S. Gattenlöhner, H. K. Müller-Hermelink, and A. Marx, "Polymerase chain reaction-based diagnosis of rhabdomyosarcomas: comparison of fetal type acetylcholine receptor subunits and myogenin," Diagnostic Molecular Pathology, vol. 7, no. 3, pp. 129-134, 1998.

[22] K. Simon-Keller, A. Paschen, S. Eichmüller et al., "Adoptive Tcell therapy of rhabdomyosarcoma," Der Pathologe, vol. 31, pp. 215-220, 2010.

[23] S. Gattenlöhner, A. Marx, B. Markfort et al., "Rhabdomyosarcoma lysis by $\mathrm{T}$ cells expressing a human autoantibody-based chimeric receptor targeting the fetal acetylcholine receptor," Cancer Research, vol. 66, no. 1, pp. 24-28, 2006.

[24] S. Poëa-Guyon, P. Christadoss, R. Le Panse et al., "Effects of cytokines on acetylcholine receptor expression: implications for myasthenia gravis," Journal of Immunology, vol. 174, no. 10, pp. 5941-5949, 2005.

[25] D. Schuhmann, P. Godoy, C. Weiß et al., "Interfering with interferon- $\gamma$ signalling in intestinal epithelial cells: selective inhibition of apoptosis-maintained secretion of antiinflammatory interleukin-18 binding protein," Clinical and Experimental Immunology, vol. 163, no. 1, pp. 65-76, 2011.

[26] M. A. Farrar and R. D. Schreiber, "The molecular cell biology of interferon- $\gamma$ and its receptor," Annual Review of Immunology, vol. 11, pp. 571-611, 1993.

[27] B. Chen, L. He, V. H. Savell, J. J. Jenkins, and D. M. Parham, "Inhibition of the interferon- $\gamma$ /signal transducers and activators of transcription (STAT) pathway by hypermethylation at a STAT-binding site in the p21(WAF1) promoter region," Cancer Research, vol. 60, no. 12, pp. 3290-3298, 2000.

[28] P. Bernabei, E. M. Coccia, L. Rigamonti et al., "Interferon- $\gamma$ receptor 2 expression as the deciding factor in human $\mathrm{T}, \mathrm{B}$, and myeloid cell proliferation or death," Journal of Leukocyte Biology, vol. 70, no. 6, pp. 950-960, 2001.

[29] I. Sadzak, M. Schiff, I. Gattermeier et al., "Recruitment of Stat 1 to chromatin is required for interferon-induced serine phosphorylation of Stat1 transactivation domain," Proceedings of the National Academy of Sciences of the United States of America, vol. 105, no. 26, pp. 8944-8949, 2008.

[30] K. M. McBride, G. Banninger, C. McDonald, and N. C. Reich, "Regulated nuclear import of the STAT1 transcription factor by direct binding of importin- $\alpha$," EMBO Journal, vol. 21, no. 7, pp. 1754-1763, 2002.
[31] N. Van Der Stoep, P. Biesta, E. Quinten, and P. J. Van Den Elsen, "Lack of IFN- $\gamma$-mediated induction of the class II transactivator (CIITA) through promoter methylation is predominantly found in developmental tumor cell lines," International Journal of Cancer, vol. 97, no. 4, pp. 501-507, 2002.

[32] P. Londhe, B. Zhu, J. Abraham, C. Keller, and J. Davie, "CIITA is silenced by epigenetic mechanisms that prevent the recruitment of transactivating factors in rhabdomyosarcoma cells," International Journal of Cancer, vol. 131, no. 4, pp. E437E448, 2012.

[33] G. Hu, A. Y. Gong, J. Liu, R. Zhou, C. Deng, and X. M. Chen, "miR-221 suppresses ICAM-1 translation and regulates interferon- $\gamma$ - induced ICAM-1 expression in human cholangiocytes," American Journal of Physiology, vol. 298, no. 4, pp. G542-G550, 2010.

[34] A. S. Dighe, E. Richards, L. J. Old, and R. D. Schreiber, "Enhanced in vivo growth and resistance to rejection of tumor cells expressing dominant negative IFN $\gamma$ receptors," Immunity, vol. 1, no. 6, pp. 447-456, 1994.

[35] D. H. Kaplan, V. Shankaran, A. S. Dighe et al., "Demonstration of an interferon $\gamma$-dependent tumor surveillance system in immunocompetent mice," Proceedings of the National Academy of Sciences of the United States of America, vol. 95, no. 13, pp. 7556-7561, 1998.

[36] G. P. Dunn, C. M. Koebel, and R. D. Schreiber, "Interferons, immunity and cancer immunoediting," Nature Reviews Immunology, vol. 6, no. 11, pp. 836-848, 2006. 


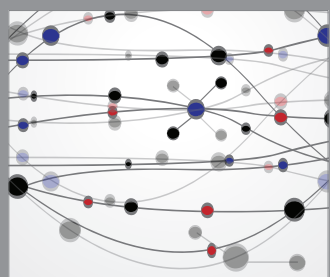

The Scientific World Journal
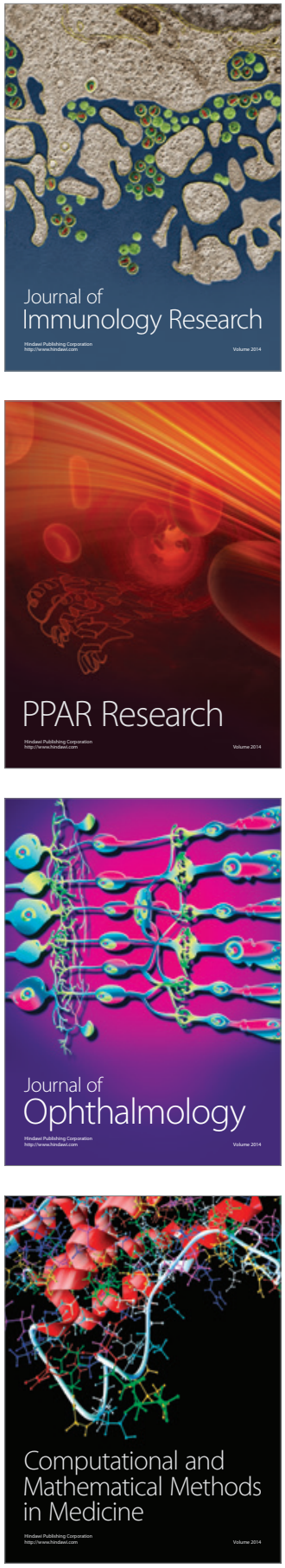

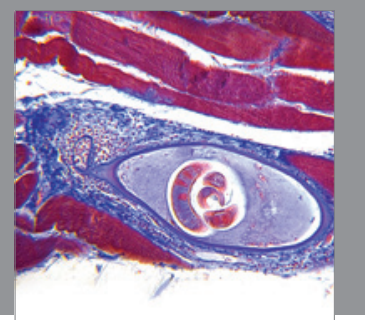

Gastroenterology

Research and Practice
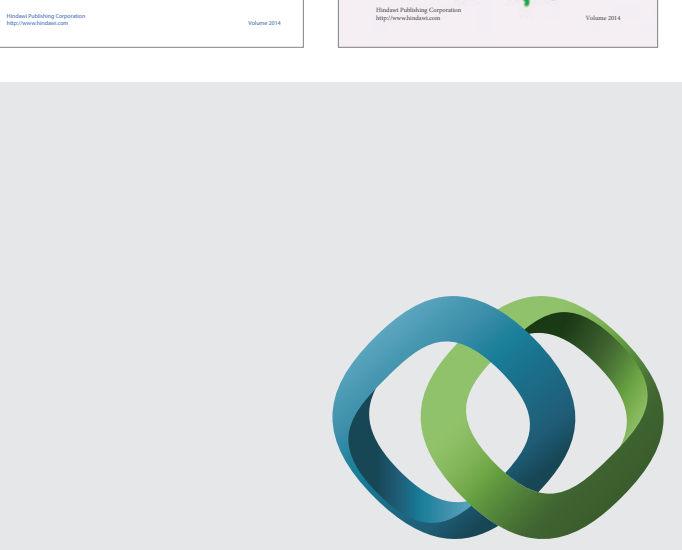

\section{Hindawi}

Submit your manuscripts at

http://www.hindawi.com
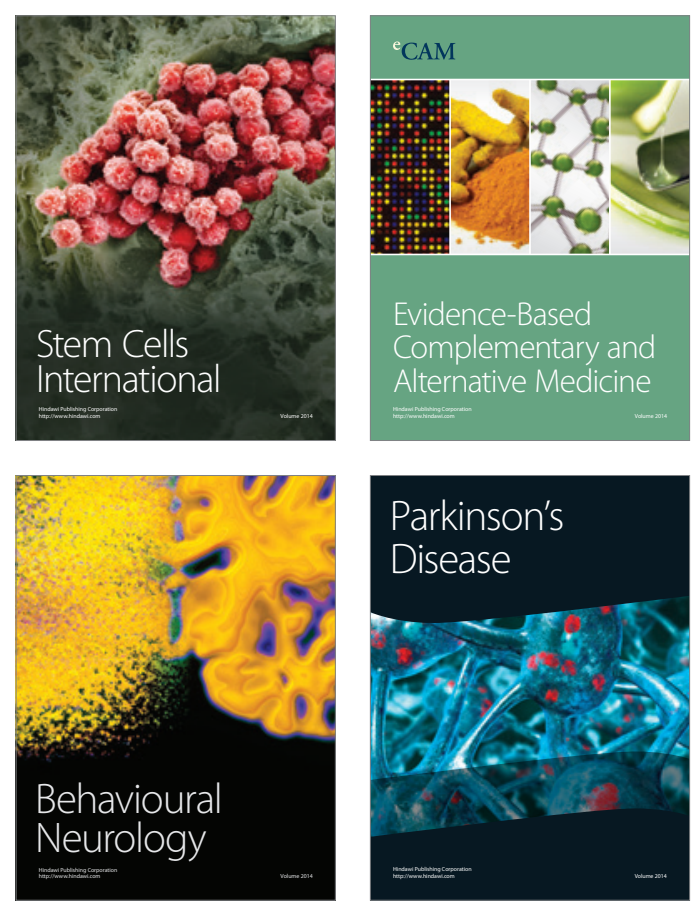

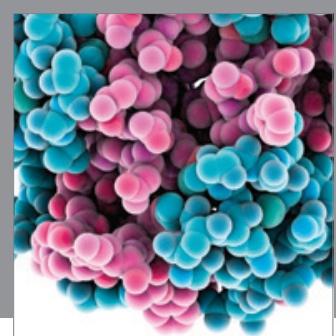

Journal of
Diabetes Research

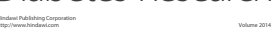

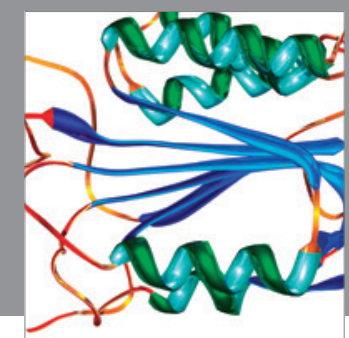

Disease Markers
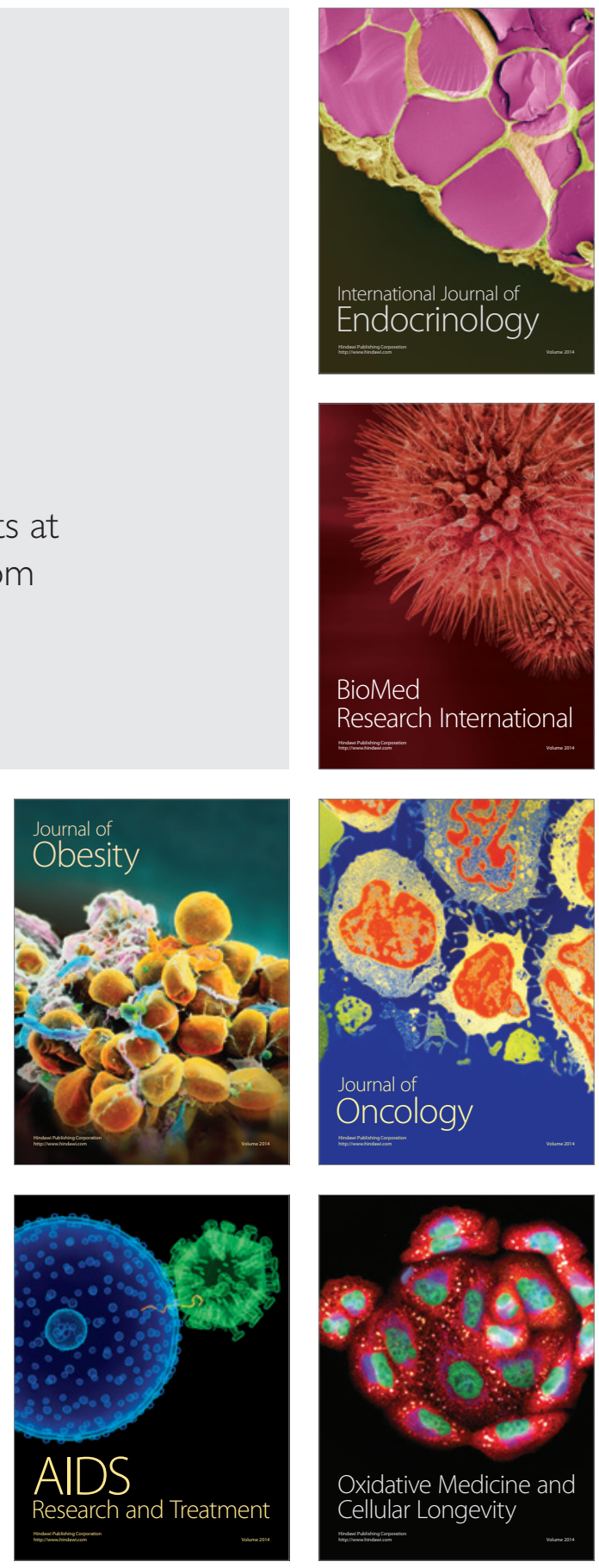